Received: 2020/03/16, Revised: 2020/03/25, Accepted: 2020/03/28, Published: 2020/03/31 ๑2020 Insu Kwon.; Licence Physical Activity and Nutrition. This is an open access article distributed under the terms of the creative commons attribution license (http://creativecommons.orglicenses/by/2.0), which permits unrestricted use, distribution, and reproduction in any medium, provided the orginal work is properly cited.

${ }^{*}$ Corresponding author : Insu Kwon, Ph.D

Research Institute of Sports Science \& Industry, Hanyang University, Seoul, Republic of Korea.

Tel: +82-10-5380-5132

E-mail: arirang0115@gmail.com

@2020 The Korean Society for Exercise Nutrition

\section{Angiotensin-converting enzyme gene insertion/deletion polymorphism is not associated with BMI in Korean adults}

\author{
Insu Kwon ${ }^{1 *}$ \\ 1. Research Institute of Sports Science \& Industry, Hanyang University, Seoul, Republic of Korea
}

\section{INTRODUCTION}

Obesity, defined as an abnormal or excessive accumulation of body fat, has become a global pandemic with a high prevalence in both adults and children ${ }^{1}$. Obesity is a direct and/or indirect risk factor for metabolic syndrome, a collection of pathological conditions comprising of abdominal obesity, dyslipidemia, hyperglycemia and hypertension ${ }^{2}$. Moreover, it is associated with a greater burden of disease, including a continuous increase in morbidity and mortality ${ }^{3}$. The etiological determinants and pathophysiological mechanisms for obesity have not yet been clearly elucidated; However, the susceptibility for developing an obese phenotype is governed by both genetic and environmental factors. Genetic factors or more specifically, obesity-related genes, are targeted for prevention strategies ${ }^{4,5}$, whereas treatment strategies rely on environmental factors including excessive food intake, physical inactivity, and stress ${ }^{6,7}$. Notably, obesogenic effects of candidate gene polymorphisms have been recently demonstrated ${ }^{4,5,8}$.

Renin angiotensin system (RAS) is a complicated hormonal cascade that mediates endocrine, paracrine, and intracrine actions. The classical 'circulating RAS' regulates the blood pressure and extracellular fluid volume whereas, the local 'tissue RAS' promotes the growth and development of most organs and tissues, s.10 $^{9}$ In the canonical pathway, a series of domino effects are triggered by renin, a key component of RAS that is released by the kidney. Renin cleaves the angiotensinogen (AGT) produced by the liver to angiotensin I (Ang I) which is subsequently converted to angiotensin II (Ang II) by angiotensin-converting enzyme (ACE) $)^{11}$. Ang II is activated by interaction with Ang II type 1 receptor (AT1) and can thereafter act as a potent vasoconstrictor to directly induce high blood pressure. The Ang II also indirectly mediates an increase in plasma volume through sodium and water reabsorption by stimulating the secretion of aldosterone, a hormone produced in the adrenal cortex ${ }^{12}$. Importantly, AGT, ACE, and Ang II expression have been observed in human adipose tissue ${ }^{13-15}$.

The major gene polymorphism of angiotensin-converting enzyme 
$(A C E)$ is characterized by the presence (insertion: I) or absence (deletion: D) of a 287 base-pair fragment within intron 16. This leads to genetic variances as evident in the II, ID, and DD genotypes ${ }^{16}$. Additionally, these genetic variants of $A C E$ are associated with different serum concentration of $A C E^{17}$. Moreover, the $\mathrm{D}$ allele of $A C E$ is likely to be involved in several chronic diseases including coronary heart disease ${ }^{18}$, diabetic nephropathy ${ }^{19}$, hypertension ${ }^{20}$, as well as obesity ${ }^{21}$. Conversely, the findings regarding the dominant effect of $A C E \mathrm{I} / \mathrm{D}$ polymorphism on obesity are inconsistent as no significant association was found in the parallel studies conducted on a cluster of Asian (Korean adult women ${ }^{22,23}$ and children ${ }^{5,24}$ ), Chinese ${ }^{25,26}$, Japanese $^{27}$, Caucasian ${ }^{21,28,29}$ and even African ${ }^{30}$ populations. No studies have been conducted evaluating the association between the $A C E \mathrm{I} / \mathrm{D}$ polymorphism and obesity in Korean adults without the population sample being stratified on the basis of sex (male/female) and age (young/elderly), even though this association should be explored within the 'population genetics' field. Therefore, this study was investigated whether the $A C E \mathrm{I} / \mathrm{D}$ polymorphism affects the susceptibility of Korean adults to develop obesity, regardless of sex or age.

\section{METHODS}

\section{Participants}

Healthy Korean adults aged between $30-82$ years were recruited, including 157 males and 196 females. The experimental procedure was approved by the Institutional Review Board; the 353 participants were provided with a basic explanation of the process and purpose of the study prior to obtaining their written consent before commencement of the study.

\section{Anthropometric indexes and blood pressure}

Height $(\mathrm{cm})$ and body weight $(\mathrm{kg})$ were measured to calculate the body mass index (BMI, $\mathrm{kg} / \mathrm{m}^{2}$ ), a measure of the body weight divided by the square of height, that served as the diagnostic criteria to distinguish between the normal and obese individuals. The criteria for categorization of the BMI of Korean adults was adopted in accordance with the 2018 guideline for the management of obesity that was provided by the Korean Society for the Study of Obesity (KSSO) ${ }^{31}$. A few parameters for anthropometric measurements including height, body weight, and percent body fat (PBF) were evaluated by bioelectrical impedance analysis (InBody 720, Korea). A BMI greater than $23 \mathrm{~kg} / \mathrm{m}^{2}$ and below $25 \mathrm{~kg} / \mathrm{m}^{2}$ was classified as overweight and a BMI greater than or equal to $25 \mathrm{~kg}$ / $\mathrm{m}^{2}$ was categorized as obese. Blood pressure (BP) was assessed by both systolic (SBP) and diastolic (DBP) blood pressures. The subjects remained stable in the sitting upright position for a minimum of 10 minutes prior to their pressure being measured on their dominant arm using a standard clinical sphygmomanometer. Hypertension was defined as SBP and DBP equal or greater to $140 \mathrm{mmHg}$ and $90 \mathrm{mmHg}$, respectively.

\section{DNA extraction and ACE I/D genotype}

Genomic DNA was isolated from whole blood cells using Puregene ${ }^{\circledR}$ DNA Purification Kit (Cat. \#D550, Gentra, USA). Firstly, 5-15 $\mu$ l of gDNA was extracted from $300 \mu \mathrm{l}$ of whole blood sample. The $A C E$ polymorphism (rs1799752) analysis was performed using the MGB TaqMan $^{\circledR}$ SNP Genotyping assay with 3 types of primers and 2 types of probes $^{32}$. The nucleotide sequences utilized in the study are as follows: Primer $A C E 111$ : 5'-CCCATC-CTT-TCT-CCC-ATT-TCT-C-3', Primer ACE112: 5'-AGC-TGG-AAT-AAA-ATT-GGC-GAA-AC-3', Primer $A C E 113$ : 5'-CCT-CCC-AAA-GTG-CTG-GGATTA-3', the I-allele-specific sequence: VIC-5'AGG-CGTGAT-ACA-GTC-A-3'-MGB, and the D-allele-specific sequence: FAM-5'TGC-TGC-CTA-TAC-AGT-CA-3'MGB. The reaction components necessary for the amplification mix were 10-50 ng gDNA, TaqMan ${ }^{\circledR}$ Genotyping Master Mix, $10 \mathrm{pmol} / \mathrm{each}$ primer, $150 \mathrm{nM}$ VIC probe, and 75 nM FAM probe. Finally, target gene amplification was performed using the ABI 7900HT Real-Time PCR system (Applied Biosystems ${ }^{\circledR}$, USA). The cycling profile included the initial denaturation at $92{ }^{\circ} \mathrm{C}$ for 15 seconds, followed by 40 cycles of annealing and extension at $57^{\circ} \mathrm{C}$ for 1 minute. The calculation for the genotypes was performed automatically (SDS Plate Utility v2.2 software, Applied Biosystems ${ }^{\circledR}$, USA).

\section{Statistical analysis}

The $A C E$ genotype and allele frequencies were obtained by direct count. The Hardy-Weinberg equilibrium for genotype distribution of each group was then estimated by the chi-square test. Differences in the allele frequencies and genotypes for the normal and overweight/ obese groups were compared using chi-square tests $(2 \times 2$ for the two groups and alleles, and $2 \times 3$ for the two groups and genotypes). Differences in the allele frequencies and genotypes between the normal, overweight, and obese groups were also analyzed using chi-square tests $(3 \times 2$ for the three groups and alleles, $3 \times 3$ for the three groups and genotypes). Multiple comparisons for the differences between the two group were performed when the chisquare test showed significant differences in the $3 \times 2$ tables for the three groups and alleles and the $3 \times 3$ tables for the three groups and genotypes. According to the criteria of Bonferroni correction, $p$-values derived from the multiple comparisons were multiplied by the number of multiple comparisons (e.g., $p$-value $\times 2$ ) to correct for false positives. Multiple logistic regression analysis was conducted to obtain the odds ratios (ORs) with $95 \%$ confidence intervals (CIs) on the relative abundance of the II or II+ID genotypes within the overweight/obese group after adjusting for sex and age. All statistical analyses were conducted using SPSS Statistics software (Version 25, IBM Corporation, IL, USA) with $p$-value $<0.05$ considered statistically significant. 


\section{RESULTS}

Clinical characteristics among the Korean adults differentiated into normal, overweight and obese groups based on their BMI

The characteristics of individuals within the normal, overweight and obese groups are shown in Table 1. The groups were categorized based on the BMI criteria for Korean adults ${ }^{31}$. Among the participants, 103 (29.2 \%) were classified as normal with a BMI $<23 \mathrm{~kg} / \mathrm{m}^{2}, 117$ (33.1\%) were classified as overweight with a $23 \mathrm{~kg} / \mathrm{m}^{2} \leq$ $\mathrm{BMI}<25 \mathrm{~kg} / \mathrm{m}^{2}$, and $133(37.7 \%)$ were grouped as obese with a BMI $\geq 25 \mathrm{~kg} / \mathrm{m}^{2}$. Anthropometric indexes, age and height were significantly higher in both overweight and obese groups compared to the normal group $(p<0.05)$. Body weight and BMI were significantly different among all three groups, whereas PBF only differed between the obese and normal groups $(p<0.05)$. SBP increased with the increase in fat storage. Additionally, obese individual had a greater DBP than in other groups $(p<0.05)$. However, no relationship between pathogenic hypertension and the stratum of obesity was observed.

Table 1. Clinical characteristics of the normal, overweight and obese groups

\begin{tabular}{|c|c|c|c|}
\hline \multirow[t]{2}{*}{ Parameters } & $\begin{array}{l}\text { Normal } \\
(n=103)\end{array}$ & $\begin{array}{l}\text { Overweight } \\
(n=117)\end{array}$ & $\begin{array}{l}\text { Obese } \\
(n=133)\end{array}$ \\
\hline & $\mathrm{BMI}<23$ & $23 \leq \mathrm{BMI}<25$ & $\mathrm{BMI} \geq 25$ \\
\hline Age (year) & $55.3 \pm 11.2^{a}$ & $59.2 \pm 11.0^{b}$ & $58.2 \pm 11.8^{b}$ \\
\hline Height (cm) & $159.2 \pm 6.8^{\mathrm{a}}$ & $161.7 \pm 8.1^{b}$ & $162.5 \pm 8.7^{b}$ \\
\hline Body weight $(\mathrm{kg})$ & $54.3 \pm 5.7^{a}$ & $62.9 \pm 6.2^{b}$ & $71.5 \pm 9.0^{c}$ \\
\hline PBF (\%) & $26.8 \pm 6.6^{\mathrm{a}}$ & $27.6 \pm 6.3^{\mathrm{a}}$ & $31.9 \pm 7.0^{b}$ \\
\hline BMI $\left(\mathrm{kg} / \mathrm{m}^{2}\right)$ & $21.4 \pm 1.1^{\mathrm{a}}$ & $24.0 \pm 0.6^{b}$ & $27.0 \pm 1.9^{c}$ \\
\hline $\mathrm{SBP}(\mathrm{mmHg})$ & $124 \pm 18^{\mathrm{a}}$ & $129 \pm 18^{b}$ & $134 \pm 16^{c}$ \\
\hline $\mathrm{DBP}(\mathrm{mmHg})$ & $75 \pm 13^{a}$ & $75 \pm 14^{a}$ & $80 \pm 16^{b}$ \\
\hline
\end{tabular}

Values are means \pm SEM. PBF=percent body fat, BMI=body mass index,

$\mathrm{SBP}=$ systolic blood pressure, $\mathrm{DBP}=$ diastolic blood pressure

Different superscripts $(a, b$, and $c)$ represent significant differences at $p<0.05$.

ACE I/D polymorphism - mediated changes in the clinical phenotypes of Korean adults

The effect of $A C E \mathrm{I} / \mathrm{D}$ polymorphism on clinically important parameters are presented in Table 2. Among the 353 participants, the II, ID and DD $A C E$ genotypes were detected in 122, 177 and 54 individuals, respectively. This cluster of $A C E$ genotypes did not differ from the expected Hardy-Weinberg equilibrium $(p=0.607)$. Additionally, most variables including age, body weight, $\mathrm{PBF}, \mathrm{BMI}$, and even SBP/DBP were not significantly altered among the $A C E$ genotypes. Contrastingly, the heights $(\mathrm{cm})$ of participants who comprised of the ID $(161.6 \pm 8.2)$ and DD genotypes $(163.7 \pm 8.0)$ were taller than those with the II genotype $(159.7 \pm 7.8)(p<0.05)$.

Association between ACE I/D polymorphism and overweight/obesity in Korean adults

The use of $A C E$ I/D polymorphism as a potential genomic biomarker in the development of obesity is indicat- ed in Table 3. The distribution of the $A C E$ genotypes were not significantly different among the normal (II: $\mathrm{n}=38$, $36.9 \%$, ID: $n=46,36.8 \%$, DD: $n=19,18.4 \%$ ), overweight (II: $\mathrm{n}=43,36.8 \%$, ID: $\mathrm{n}=55,47.0 \%$, DD: $\mathrm{n}=19,16.2 \%$ ), and obese (II: $n=41,30.8 \%$, ID: $n=76,57.0 \%$, DD: $n=16$, $12.0 \%$ ) groups. Unexpectedly, the I allele (normal: $\mathrm{n}=122$, $48.8 \%$, overweight: $n=141,60.3 \%$, obese: $n=158,59.4$ $\%$ ) was preferred over the $\mathrm{D}$ allele (normal: $\mathrm{n}=84,51.2$ $\%$, overweight: $n=93,39.7 \%$, obese: $n=108,40.6 \%$ ) in obese individuals. OR and $95 \% \mathrm{CI}$ were used to calculate the strength of association in the allele and genotype frequencies of the overweight and obese groups against the normal group, respectively.

A greater proportion of participants with the ID genotype were intended to being overweight (OR: 1.06, 95\% CI: $0.58 \sim 1.90$ ) and obese (OR: 1.13, 95\% CI: 0.63 2.04), compared to the lower proportion of participants with the DD genotype was likely to being overweight (OR: $0.88,95 \%$ CI: 0.49 1.91) and obese (OR: 0.78, 95\% CI: $0.35 \sim 1.73)$. Besides, the newly generated II+ID genotype appears to be associated with a greater proportion of individuals being overweight (OR: $0.83,95 \%$ CI: $0.41 \sim 1.67$ ) and obese (OR: $0.58,95 \%$ CI: $0.28 \sim 1.20$ ) compared to the normal. Thus, the data suggests that the ACE I/D polymorphism does not affect the risk of obesity in Korean adults.

Table 2. Characteristics of individuals grouped in accordance to their ACE genotypes

\begin{tabular}{|c|c|c|c|c|}
\hline \multirow[b]{2}{*}{ Parameters } & \multicolumn{3}{|c|}{ ACE genotypes } & \multirow[b]{2}{*}{$\begin{array}{c}\text { HWE } \\
(p=0.607)\end{array}$} \\
\hline & $\begin{array}{c}\text { II } \\
(n=122)\end{array}$ & $\begin{array}{c}\text { ID } \\
(n=177)\end{array}$ & $\begin{array}{c}D D \\
(n=54)\end{array}$ & \\
\hline Age (year) & $60.0 \pm 11.5$ & $57.6 \pm 11.4$ & $57.2 \pm 11.8$ & \\
\hline Height (cm) & $159.7 \pm 7.8^{\mathrm{a}}$ & $161.6 \pm 8.2^{b}$ & $163.7 \pm 8.0^{b}$ & \\
\hline Body weight $(\mathrm{kg})$ & $62.3 \pm 9.4$ & $64.2 \pm 10.2$ & $64.9 \pm 10.9$ & \\
\hline PBF (\%) & $29.9 \pm 7.0$ & $28.7 \pm 6.9$ & $27.8 \pm 7.3$ & \\
\hline BMI $\left(\mathrm{kg} / \mathrm{m}^{2}\right)$ & $24.3 \pm 2.5$ & $24.5 \pm 2.6$ & $24.1 \pm 3.1$ & \\
\hline $\mathrm{SBP}(\mathrm{mmHg})$ & $127 \pm 16$ & $131 \pm 18$ & $129 \pm 17$ & \\
\hline $\mathrm{DBP}(\mathrm{mmHg})$ & $79 \pm 9$ & $76 \pm 17$ & $75 \pm 14$ & \\
\hline
\end{tabular}

Values are means \pm SEM. PBF=percent body fat, $\mathrm{BMI}=$ body mass index,

$\mathrm{SBP}=$ systolic blood pressure, $\mathrm{DBP}=$ diastolic blood pressure,

HWE=Hardy-Weinberg equilibrium.

Different superscripts ( $a$ and $b$ ) represent significant differences at $p$ $<0.05$.

Table 3. Genotype and allele frequencies of the ACE gene polymorphism among the normal, overweight and obese groups

\begin{tabular}{|c|c|c|c|c|c|}
\hline Genotypes & $\begin{array}{l}\text { Normal } \\
(n=103)\end{array}$ & $\begin{array}{l}\text { Overweight } \\
(n=117)\end{array}$ & $\begin{array}{c}\text { Obese } \\
(n=133)\end{array}$ & $\begin{array}{c}\text { Overweight } \\
\text { vs Normal } \\
\text { OR } \\
(95 \% \mathrm{Cl})\end{array}$ & $\begin{array}{c}\begin{array}{c}\text { Obese } \\
\text { vs Normal }\end{array} \\
\text { OR } \\
(95 \% \mathrm{Cl})\end{array}$ \\
\hline$\|(n=122)$ & $38(36.9)$ & $43(36.8)$ & $41(30.8)$ & - & - \\
\hline $\mathrm{ID}(\mathrm{n}=177)$ & $46(36.8)$ & $55(47.0)$ & $76(57.1)$ & $1.06(0.58 \sim 1.90)$ & $1.13(0.63 \sim 2.04)$ \\
\hline $\mathrm{DD}(\mathrm{n}=54)$ & $19(18.4)$ & $19(16.2)$ & $16(12.0)$ & $0.88(0.49 \sim 1.91)$ & $0.78(0.35 \sim 1.73)$ \\
\hline$\|++\mid \mathrm{D}(v s . \mathrm{DD})$ & $84(81.6)$ & $98(83.8)$ & $117(88.0)$ & $0.83(0.41 \sim 1.67)$ & $0.58(0.28 \sim 1.20)$ \\
\hline I allele & $122(48.8)$ & $141(60.3)$ & $158(59.4)$ & & \\
\hline D allele & $84(51.2)$ & $93(39.7)$ & $108(40.6)$ & & \\
\hline
\end{tabular}




\section{DISCUSSION}

The present study is the first to investigate the association between the $A C E \mathrm{I} / \mathrm{D}$ polymorphism and susceptibility for overweight/obesity of healthy Korean adults. The data obtained from the adult population was not subdivided into age and sex to ensure a massive and representative cluster so that any negative impact of selection bias can be eliminated.

Overweight/obesity is a multifactorial disease that is frequently associated with comorbidities including chronic diseases. As a result of the rising prevalence, morbidity and mortality rates of obesity, prevention strategies remain an essential focus. Hence, it is imperative to determine if the gene-environment interactions exacerbate the genotype-phenotype relationship.

Considering the role of local RAS in regulating obesity, Ang II, a potent vasoconstrictor, promotes lipogenesis in adipocytes ${ }^{33}$. Moreover, genetic variants of $A C E$ have been implicated in adipogenesis and metabolic disease ${ }^{34-36}$. Therefore, the association between $A C E$ I/D polymorphism and obesity is plausible, as illustrated in several studies ${ }^{21-23}$.

The observations made in this study are as follows: (i) hypertension was not a pathological occurrence of obesity; However, BP (SBP and DBP) was higher in obese (BMI $\geq$ 25 ) individuals compared to normal. (ii) $A C E$ genotypes do not have any impact on obesity and hypertension. Previously, Um et $\mathrm{al}^{22}$ also found no association between $A C E \mathrm{I} /$ $\mathrm{D}$ polymorphism and obesity in Korean women. Moreover, Thomas et $\mathrm{al}^{37}$ proposed that pathological hypertension is not associated with $A C E$ I/D polymorphism. (iii) ID genotype is proposed to be the most vulnerable to the development of obesity compared to the DD and ID+DD genotype; However, it's association with obesity is not statistically favorable. Contrary to this findings, previous studies have shown a positive association between $A C E$ I/D polymorphism and obesity, as the D allele of the ACE gene is frequently detected in younger obese men including preschool children, children and adolescents ${ }^{5,28}$. Furthermore, a recent meta-analysis study suggested that the DD genotype is related to a higher susceptibility for overweight/obesity in an overall population, especially in Africans ${ }^{8}$. BMI is closely associated with the overall subcutaneous fat mass but is a poor predictor of central obesity (abdominal and visceral) when compared to waist circumference. Thus, further studies using the gold-standard measurement for body composition are required, with a large sample-size in both the adults and elderly populations. Moreover, a genetic predisposition to obesity primarily focusses on single nucleotide polymorphisms (SNPs); However, environmental and epigenetic factors have been recently recognized to be contributors for the development of obesity ${ }^{38}$. The limitations of this study include the potential contribution of confounding factors (obesity-related blood parameters and a history of medications). However, this study can be used to support further studies in Korean clusters.

In conclusion, $A C E \mathrm{I} / \mathrm{D}$ polymorphism has not been observed to be a powerful candidate gene for obesity in Kore- an adults.

\section{ACKNOWLEDGEMENTS}

The author declares that there is no conflict of interest regarding the publication of this article.

\section{REFERENCES}

1. Apovian CM, Riffenburg KM. Perspectives on the global obesity epidemic. Curr Opin Endocrinol Diabetes Obes. 2017;24:307-9.

2. Engin A. The Definition and Prevalence of Obesity and Metabolic Syndrome. Adv Exp Med Biol. 2017;960:1-17.

3. Gregg EW, Shaw JE. Global Health Effects of Overweight and Obesity. N Engl J Med. 2017;377:80-1.

4. Ergören MC, Söyler G, Sah H, Becer E. Investigation of potential genomic biomarkers for obesity and personalized medicine. Int J Biol Macromol. 2019;122:493-8.

5. Yoo KH, Yim HE, Bae ES, Hong YS. Genetic Contributions to Childhood Obesity: Association of Candidate Gene Polymorphisms and Overweight/Obesity in Korean Preschool Children. J Korean Med Sci. 2017;32:1997-2004.

6. Sinha R, Jastreboff AM. Stress as a common risk factor for obesity and addiction. Biol Psychiatry. 2013;73:827-35.

7. Raynor HA, Champagne CM. Position of the Academy of Nutrition and Dietetics: Interventions for the Treatment of Overweight and Obesity in Adults. J Acad Nutr Diet. 2016;116:12947.

8. Mao S, Huang S. A meta-analysis of the association between angiotensin-converting enzyme insertion/ deletion gene polymorphism and the risk of overweight/obesity. J Renin Angiotensin Aldosterone Syst. 2015;16:687-94.

9. Fyhrquist $F$, Saijonmaa O. Renin-angiotensin system revisited. J Intern Med. 2008;264:224-36.

10. Kumar R, Singh VP, Baker KM. The intracellular renin-angiotensin system: a new paradigm. Trends Endocrinol Metab. 2007;18:208-14.

11. Peach MJ. Renin-angiotensin system: biochemistry and mechanisms of action. Physiol Rev. 1977;57:313-70.

12. Kaschina E, Unger T. Angiotensin AT1/AT2 receptors: regulation, signalling and function. Blood Press. 2003;12:70-88.

13. Crandall DL, Herzlinger HE, Saunders BD, Armellino DC, Kral JG. Distribution of angiotensin II receptors in rat and human adipocytes. J Lipid Res. 1994;35:1378-85.

14. Jones BH, Standridge MK, Taylor JW, Moustaid N. Angiotensinogen gene expression in adipose tissue: analysis of obese models and hormonal and nutritional control. Am J Physiol. 1997;273:R236-42

15. Jonsson JR, Game PA, Head RJ, Frewin DB. The expression and localisation of the angiotensin-converting enzyme mRNA in human adipose tissue. Blood Press. 1994;3:72-5.

16. Danser AH, Schalekamp MA, Bax WA, van den Brink AM, Saxena PR, Riegger GA, Schunkert H. Angiotensin-converting enzyme in the human heart. Effect of the deletion/insertion polymorphism. Circulation. 1995;92:1387-8. 
17. Rigat B, Hubert C, Alhenc-Gelas F, Cambien F, Corvol P, Soubrier F. An insertion/deletion polymorphism in the angiotensin I-converting enzyme gene accounting for half the variance of serum enzyme levels. J Clin Invest. 1990;86:1343-6.

18. Cambien F, Poirier O, Lecerf L, Evans A, Cambou JP, Arveiler D, Luc G, Bard JM, Bara L, Ricard S, Tiret L, Amouyel P, Alhenc-Gelas F, Soubrier F. Deletion polymorphism in the gene for angiotensin-converting enzyme is a potent risk factor for myocardial infarction. Nature. 1992;359:641-4.

19. Hadjadj S, Belloum R, Bouhanick B, Gallois Y, Guilloteau G, Chatellier G, Alhenc-Gelas F, Marre M. Prognostic value of angiotensin-I converting enzyme I/D polymorphism for nephropathy in type 1 diabetes mellitus: a prospective study. $J$ Am Soc Nephrol. 2001;12:541-9.

20. Di Pasquale P, Cannizzaro S, Scalzo S, Maringhini G, Pipitone F, Fasullo S, Giubilato A, Ganci F, Vitale G, Sarullo FM, Paterna S. Cardiovascular effects of I/D angiotensin-converting enzyme gene polymorphism in healthy subjects. Findings after follow-up of six years. Acta Cardiol. 2005;60:427-35.

21. Sun C, Ponsonby AL, Carlin JB, Bui M, Magnussen CG, Burns TL, Lehtimaki T, Wardrop NH, Juonala M, Viikari JSA, Venn AJ, Raitakari OT, Dwyer T. Childhood adiposity, adult adiposity, and the ACE gene insertion/deletion polymorphism: evidence of gene-environment interaction effects on adult blood pressure and hypertension status in adulthood. $J \mathrm{Hy}$ pertens. 2018;36:2168-76.

22. Um JY, Mun KS, An NH, Kim PG, Kim SD, Song YS, Lee KN, Lee KM, Wi DH, You YO, Kim HM. Polymorphism of angiotensin-converting enzyme gene and $\mathrm{BMI}$ in obese Korean women. Clin Chim Acta. 2003;328:173-8.

23. Kim K. Association of angiotensin-converting enzyme insertion/deletion polymorphism with obesity, cardiovascular risk factors and exercise-mediated changes in Korean women. Eur J Appl Physiol. 2009;105:879-87.

24. Yang SJ, Kim S, Park H, Kim SM, Choi KM, Lim Y, Lee M. Sex-dependent association between angiotensin-converting enzyme insertion/deletion polymorphism and obesity in relation to sodium intake in children. Nutrition. 2013;29:525-30.

25. Thomas GN, Critchley JA, Tomlinson B, Lee ZS, Young RP, Cockran CS, Chan JC. Albuminuria and the renin-angiotensin system gene polymorphisms in type-2-diabetic and in normoglycemic hypertensive Chinese. Clin Nephrol. 2001;55:7-15.

26. Shan J, Shi Y, Fu G. [The relationship between angiotensin converting enzyme gene polymorphism and risk factors for coronary heart disease]. Zhonghua Liu Xing Bing Xue Za Zhi. 2000;21:208-11.

27. Uemura K, Nakura J, Kohara K, Miki T. Association of ACE I/ $\mathrm{D}$ polymorphism with cardiovascular risk factors. Hum Genet. 2000;107:239-42.

28. Lemes VA, Neves AL, Guazzelli IC, Frazzatto E, Nicolau C, Corrêa-Giannella ML, Velho G, Villares SM. Angiotensin converting enzyme insertion/deletion polymorphism is associated with increased adiposity and blood pressure in obese children and adolescents. Gene. 2013;532:197-202.

29. Strazzullo $P$, lacone $R$, lacoviello $L$, Russo O, Barba $G$, Russo P, D'Orazio A, Barbato A, Cappuccio FP, Farinaro E, Siani A; Olivetti Prospective Heart Study. Genetic variation in the renin-angiotensin system and abdominal adiposity in men: the Olivetti Prospective Heart Study. Ann Intern Med. 2003;138:17-23.

30. Kramer H, Wu X, Kan D, Luke A, Zhu X, Adeyemo A, McKenzie $C$, Cooper R. Angiotensin-converting enzyme gene polymorphisms and obesity: an examination of three black populations. Obes Res. 2005;13:823-8.

31. Seo MH, Lee WY, Kim SS, Kang JH, Kang JH, Kim KK, Kim BY, Kim YH, Kim WJ, Kim EM, Kim HS, Shin YA, Shin HJ, Lee KR, Lee KY, Lee SY, Lee SK, Lee JH, Lee CB, Chung S, Cho YH, Choi KM, Han JS, Yoo SJ; Committee of Clinical Practice Guidelines, Korean Society for the Study of Obesity (KSSO). 2018 Korean Society for the Study of Obesity Guideline for the Management of Obesity in Korea. J Obes Metab Syndr. 2019;28:40-5.

32. Koch W, Latz W, Eichinger M, Ganser C, Schomig A, Kastrati A. Genotyping of the angiotensin I-converting enzyme gene insertion/deletion polymorphism by the TaqMan method. Clin Chem. 2005;51:1547-9.

33. Jones BH, Standridge MK, Moustaid N. Angiotensin II increases lipogenesis in 3T3-L1 and human adipose cells. Endocrinology. 1997;138:1512-9.

34. Pan $\mathrm{YH}$, Wang $M$, Huang $\mathrm{YM}$, Wang $\mathrm{YH}$, Chen $\mathrm{YL}$, Geng LJ, Zhang XX, Zhao HL. ACE Gene I/D Polymorphism and Obesity in 1,574 Patients with Type 2 Diabetes Mellitus. Dis Markers. 2016;2016:7420540.

35. Xi B, Ruiter R, Chen J, Pan H, Wang Y, Mi J. The ACE insertion/deletion polymorphism and its association with metabolic syndrome. Metabolism. 2012;61:891-7.

36. Kim K, Ahn N, Park J, Koh J, Jung S, Kim S, Moon S. Association of angiotensin-converting enzyme I/D and alpha-actinin-3 R577X genotypes with metabolic syndrome risk factors in Korean children. Obes Res Clin Pract. 2016;10 Suppl 1:S125-32.

37. Thomas GN, Tomlinson B, Chan JC, Sanderson JE, Cockram $\mathrm{CS}$, Critchley JA. Renin-angiotensin system gene polymorphisms, blood pressure, dyslipidemia, and diabetes in Hong Kong Chinese: a significant association of tne ACE insertion/ deletion polymorphism with type 2 diabetes. Diabetes Care. 2001;24:356-61.

38. Singh RK, Kumar P, Mahalingam K. Molecular genetics of human obesity: A comprehensive review. C R Biol. 2017;340:87108. 